\title{
TASKS SOLVED IN THE ANALYSIS OF THE ENTERPRISE'S LABOR RESOURCES
}

\author{
V.V. Zakharov, metkol@yandex.ru \\ South Ural State University, Chelyabinsk, Russian Federation
}

\begin{abstract}
The enterprise, as an economic system, is the main primary link, where there is a direct solution to the main economic problem of efficient allocation and management of resources.

In the light of constantly growing requirements to optimization of economic activity of the enterprise and for implementation of its principles and strategy it is necessary to estimate and consider financial and economic condition of the enterprise, including in the field of manpower, as the most important component of administrative activity.

The production potential of the enterprise is formed from the availability, as well as the effectiveness and efficiency of the use of both means of labor, objects of labor, and the actual labor resources, in accordance with this, and the analysis is conducted. The vector for evaluation and decision-making in the field of human resources is the analysis of human resources of the enterprise and the efficiency of their use. It should be noted that with the transition to a market economy, the analysis of labour relations becomes increasingly important, since the labour force is valued and competitive in the labour market. This extends the boundaries of analytical research, the criteria for optimizing labor relations have not only economic but also social parameters. Economic and social security of labor, on the one hand, and special working conditions, on the other, form the sphere of in-depth analytical studies of the enterprise's potential. It is also important to give a correct assessment of the use of resources of the organization with the help of the main indicators of the enterprise. This article discusses the analysis of labor resources as one of the components of the formation and use of the production potential of the enterprise.
\end{abstract}

Keywords: analysis of labor resources, personnel management.

\section{Introduction}

There are various ways to analyze the financial and economic condition of the enterprise [1-5]. However, some areas of analysis of the state of the enterprise are the most common [6-8]. Let us consider in more detail the analysis of labor resources as a component of the formation and use of the production potential of the enterprise.

\section{To the analysis of labor resources}

In the analysis of labor resources the following tasks are solved [9]:

- assessment of staffing levels;

- analysis of staff composition, structure and movement;

- evaluation of the effectiveness of working time;

- analysis of the effectiveness using of labor resources, identification and calculation of reserves of efficiency growth.

For the enterprise, both the deficit and the surplus of labor resources are disadvantageous. The deficit, as a rule, has the following negative consequences: the growth of overtime work and the associated overspending of the wage fund; non-rhythmic production; failure to plan production; reduced product quality. All these factors lead to an increase in production costs, penalties and, consequently, to lower profits. Surplus labor with a constant volume of production leads to a decrease in labor productivity, which also leads to an increase in production costs [10-12].

Movement analysis is performed in absolute and relative terms by categories of personnel. The most important category for the analysis are the workers of the main production, since it is they who produce the additional product and the cost of paying for their labor is direct, that is, they are directly transferred to the cost of products. In addition to this category, employees of auxiliary and service industries, employees, etc., are also distinguished. In addition to the categories, personnel analysis can be made on other factors: gender and age, education, marital status, etc. [9, 13-15]. 


\section{Краткие сообщения}

Analysis of the movement of personnel is assessed using absolute indicators, and using coefficients:

$$
\begin{aligned}
& \text { Acceptance turnover ratio }=\frac{\text { Number of applicants }}{\text { Average number }}, \\
& \text { Turnover rate for retirement }=\frac{\text { Number of departures }}{\text { Average number }}, \\
& \text { Staff turnover rate }=\frac{\begin{array}{c}
\text { The number of dismissed (of their own free will } \\
\text { and for violation of the discipline) }
\end{array}}{\text { Average number }} .
\end{aligned}
$$

However, analyzing only the availability of labor resources is not enough; it is important to evaluate the effectiveness of their use. Two factors are considered: the use of working time (extensive factor) and labor productivity (intensive factor).

For the analysis of working time calculated funds time (calendar, nominee, person helpful, and so on) that are mapped to the dynamics of the actual funds previous periods. The influence of factors on the change of temporary funds is studied by the balance sheet method.

Labor productivity refers to the indicators of local efficiency, that is, it compares the result and the expended resource. In practice, several indicators of labor productivity are used:

- production per person [monetary unit]:

$$
P T_{1}=\frac{\text { Output in value terms }}{\text { Number }}
$$

characterizes the cost of products produced by one person per month;

- production output [piece/person-hour]:

$$
P T_{2}=\frac{\text { output in natural terms }}{\text { Cost of working time }}
$$

characterizes the amount of products produced per unit of time;

- labor intensity:

$$
T_{\text {ins }}=\frac{\text { Costs (person-hours) }}{\text { Output in value terms }}
$$

characterizes the complexity of the monetary unit of production;

- specific labor intensity:

$$
T_{\text {ins.spec }}=\frac{\text { Costs (man-hours) }}{\text { output in physical terms }}
$$

characterizes the complexity of manufacturing a unit of production.

Factor analysis of labor productivity is carried out by the method of chain substitutions, by the method of differences or by the integral method. Factors affecting productivity are:

- number of working days;

- the average duration of the working day;

- the average hourly production of workers, which depends on the product range, the technical level of production, changes in the specific labor intensity of products.

The generalized indicators of the efficiency of use of labor resources include the indicator of relative savings (overspending) of costs, as well as the ratio of growth rates of labor productivity and wages:

$$
\text { Overspending labor costs }=C_{1}-C_{0} \cdot K_{\text {growth }} \text {, }
$$

where $C_{1}$ - actual labor costs of the current period;

$C_{0}$ - planned labour costs;

$K_{\text {growth }}-$ growth rate of output calculated as:

$K=\frac{\text { Growth rate of labor productivity }}{\text { Growth rate of average wage }}$.

The values of this coefficient more than 1 shows that the use of labor resources in the enterprise is quite effective.

\section{Conclusion}

The labor resources in an enterprise is the object of constant management attention. The volume and timeliness of all work, the degree of use of equipment and, consequently, the volume of production, its 
cost, profit and a number of other economic indicators depend on the security of the enterprise with labor resources and the efficiency of their use, in this regard, it is necessary to analyze the labor resources of the enterprise.

\section{References}

1. Vasiliev D.K., Zalozhnev A.Yu., Novikov D.A. Tipovyye resheniya v upravlenii proyektami [Typical Solutions in Project Management]. Moscow, ICS RAS Publ., 2003. 84 p.

2. Monakhov A.V. Matematicheskiye metody analiza ekonomiki [Mathematical Methods of Economic Analysis]. St. Petersburg, Piter Publ., 2002. 176 p.

3. Novikov D.A. Stimulirovaniye v organizatsionnykh sistemakh [Stimulation in Organizational Systems]. Moscow, Sinteg Publ., 2003. 305 p.

4. Korennaya K.A. [Approach, Methods and Models of Labor Resources Management as the Most Important Components of the Modern Concept of Industrial Enterprise Management]. News of Higher Educational Institutions. Ural Region, 2012, no 3, pp. 47-61. (in Russ.)

5. Korennaya K.A., Loginovsky O.V., Maksimov A.A. Upravlenie promyshlennymi predpriyatiyami $v$ usloviyakh global'noy nestabil'nosti [Industrial Enterprises Management in Conditions of Global Instability]. Chelyabinsk, South Ural St. Univ. Publ., 2013. 403 p.

6. Loginovskiy O.V., Bolodurina I.P. Gosudarstvennoye upravleniye promyshlennost'yu $v$ regionakh $R F$ [State Management of Industry in the Regions of the Russian Federation]. Moscow, Mechanical Engineering, 2003. 75 p.

7. Loginovskiy O.V., Burkov V.N., Burkova I.V., Gel'rud Ya.D., Korennaya K.A., Maksimov A.A., Shestakov A.L. Upravleniye promyshlennymi predpriyatiyami: strategii, mekhanizmy, sistemy [Management of Industrial Enterprises: Strategies, Mechanisms, Systems]. Moscow, INFRA-M Publ., 2018. 410 p.

8. Loginovskiy O.V., Maksimov A.A. Upravlenie: teorija i praktika. T. 1: Upravleniye promyshlennym predpriyatiyem [Management: Theory and Practice. Vol. 1: Industrial Enterprise Management]. Moscow, Mechanical Engineering-1 Publ., 2006. 576 p.

9. Loginovskiy O.V., Maksimov A.A. Upravlenie: teorija i praktika. T. 2: Korporativnoye upravleniye [Management: Theory and Practice. Vol. 2: Corporate Governance]. Moscow, Mechanical Engineering-1 Publ., 2007. 624 p.

10. Novikov D.A. Teoriya upravleniya organizatsionnymi sistemami [Theory of Management of Organizational Systems]. Moscow, Publ. House of Physical and Mathematical Literature, 2012. 604 p.

11. Rayzberg B.A. Kurs upravleniya ekonomikoy [Economics Management Course]. St. Petersburg, Piter Publ., 2003. 528 p.

12. Druri K. Upravlencheskiy uchet dlya biznes-resheniy [Management Accounting for Business Decisions]. Moscow, UNITY-DANA Publ., 2003. 665 p.

13. Fidel'man G.N., Dedikov S.V., Adler Yu.P. Al'ternativnyy menedzhment: put' $k$ global'noy konkurentosposobnosti [Alternative Management: The Path to Global Competitiveness]. Moscow, Al'pina Publ., 2005. 186 p.

14. Alekseenko V.B., Ivanova T.B. Kak dostich' effektivnosti $v$ upravlenii biznesom [How to Achieve Efficiency in Business Management]. Moscow, RUDN Univ. Publ., 2010. 214 p.

15. Egorshin A.P. Upravleniye personalom [Human Resource Management]. N. Novgorod, NIMB Publ., 1999. 214 p.

Received 28 January 2019 


\title{
ЗАДАЧИ, РЕШАЕМЫЕ ПРИ АНАЛИЗЕ ТРУДОВЫХ РЕСУРСОВ ПРЕДПРИЯТИЯ
}

\author{
B.B. Захаров
}

Южно-Уральский государственный университет, г. Челябинск, Россия

\begin{abstract}
Предприятие как экономическая система является главным первичным звеном, где происходит непосредственное решение основной экономической проблемы эффективного распределения ресурсов и управления ими.

В свете постоянно растущих требований к оптимизации хозяйственной деятельности предприятия и для реализации его принципов и стратегии необходимо оценивать и учитывать финансово-экономическое состояние предприятия, в том числе в области трудовых ресурсов, как важнейшей составляющей управленческой деятельности.

Производственный потенциал предприятия формируется из наличия, а также результативности и эффективности использования как средств труда, предметов труда, так и собственно трудовых ресурсов, в соответствии с этим и ведется анализ. Вектором для оценки и принятия решений в области трудовых ресурсов является анализ трудовых ресурсов предприятия и эффективности их использования. Следует отметить, что с переходом к рыночной экономике анализ трудовых отношений становится все более важным, поскольку рабочая сила имеет оценку и является конкурентоспособной на рынке труда. Это расширяет границы аналитических исследований, критерии оптимизации трудовых отношений имеют не только экономические, но и социальные параметры. Экономическое и социальное обеспечение труда, с одной стороны, и особые условия труда, с другой, формируют сферу углубленных аналитических исследований потенциала предприятия. Также важно дать правильную оценку использованию ресурсов организации с помощью основных показателей предприятия. В данной статье рассматривается анализ трудовых ресурсов как один из составляющих компонентов формирования и использования производственного потенциала предприятия.

Ключевые слова: анализ трудовых ресурсов, управление персоналом.
\end{abstract}

\section{Литература}

1. Типовые решения в управлении проектами / Д.К. Васильев, А.Ю. Заложнев, Д.А. Новиков и др. - М.: ИПУ РАН, 2003. -84 c.

2. Монахов, А.В. Математические методы анализа экономики / А.В. Монахов. - СПб.: Пиmep, 2002. $-176 c$.

3. Новиков, Д.А. Стимулирование в организащионных системах / Д.А. Новиков. - М.: Синтег, 2003. $-305 c$.

4. Коренная, К.А. Подход, методы и модели управления трудовыми ресурсами как важснейшие составляющие современной концепции управления промышленным предприятием / К.А. Коренная // Известия выстих учебных заведений. Уральский регион. -2012. - № 3. - С. 47-61.

5. Коренная, К.А. Управление промышленными предприятиями в условиях глобальной нестабильности: монография / К.А. Коренная, О.В. Логиновский, А.А. Максимов; под ред. д-ра техн. наук проф. А.Л. Шестакова // - Челябинск: Издат. иентр ЮУрГУ, 2013. - 403 с.

6. Логиновский, О.В. Государственное управление промьишленностью в регионах РФ / О.В. Логиновский, И.П. Болодурина. - М.: Машиностроение, 2003. - 75 c.

7. Управление промышленными предприятиями: стратегии, механизмы, системы: моногр. / О.В. Логиновский, В.Н. Бурков, И.В. Буркова и др. - М.: ИНФРА-М, 2018. - 410 с.

8. Логиновский, О.В. Управление: теория и практика. Т. 1: Управление промышленным предприятием / О.В. Логиновский, А.А. Максимов. - М.: Машиностроение, 2006. - 576 с.

9. Логиновский, О.В. Управление: теория и практика. Т. 2: Корпоративное управление / О.В. Логиновский, А.А. Максимов. - М.: Машиностроение-1, 2007. - 624 с.

10. Новиков, Д.А. Теория управления организационными системами / Д.А. Новиков. - 3-е изд. М.: Изд-во физ.-мат. лит., 2012. - 604 с. 
11. Райзберг, Б.А. Курс управления экономикой / Б.А. Райзберг. - СПб.: Питер, 2003. - 528 с.

12. Друри, К. Управленческий учет для бизнес-решений / К. Друри. - М.: ЮНИТИ-ДАНА, 2003. $-665 c$.

13. Фидельман, Г.Н. Альтернативный менеджмент: путь к глобальной конкурентоспособности / Г.Н. Фидельман, С.В. Дедиков, Ю.П. Адлер. - М.: Альпина, 2005. - 186 с.

14. Алексеенко, В.Б. Как достичь эффективности в управлении бизнесом / В.Б. Алексеенко, Т.Б. Иванова - М.: Изд-во РУДН, 2010. - 214 с.

15. Егоршин, А.П. Управление персоналом / А.П. Егоршин. - Н. Новгород: НИМБ, 1999. - 214 c.

Захаров Вадим Владимирович, аспирант кафедры информационно-аналитического обеспечения управления в социальных и экономических системах, Южно-Уральский государственный университет, г. Челябинск; metkol@yandex.ru.

Поступила в редакцию 28 января 2019 г.

\section{ОБРАЗЕЦ ЦИТИРОВАНИЯ}

Zakharov, V.V. Tasks Solved in the Analysis of the Enterprise's Labor Resources / V.V. Zakharov // Вестник ЮУрГУ. Серия «Компьютерные технологии, управление, радиоэлектроника». - 2019. - Т. 19, № 2. - C. 175-179. DOI: $10.14529 /$ ctcr190217

\section{FOR CITATION}

Zakharov V.V. Tasks Solved in the Analysis of the Enterprise's Labor Resources. Bulletin of the South Ural State University. Ser. Computer Technologies, Automatic Control, Radio Electronics, 2019, vol. 19, no. 2 , pp. $175-179$. DOI: $10.14529 /$ ctcr 190217 